\title{
BULGARIA IN THE TRANSPORT SYSTEMS OF EUROPE
}

DOI: http://dx.doi.org/10.18509/GBP.2020.30

UDC: 656(497.2:4-672EU)

\author{
Atanas Dermendzhiev \\ Martin Doykov \\ Department of Geography, Faculty of History, "St. Cyril and St. Methodius" \\ University of Veliko Tarnovo, Bulgaria
}

\begin{abstract}
The contemporary development of Southeastern Europe predetermines the necessity of the existence of adequate transport connections. The linear infrastructure of Bulgaria is a complicated system, determining the socio-economic and geodemographic development of the country, but also determined by the level of its condition.

The political-economic dualism substantiates the variability and adaptiveness of the attitude to transport activity conditions. The Bulgarian geopolitical space is a dynamic area. Its fundamental frame is the transport network, predetermined by the requirements for adequate valorization of the political-geographical position of Bulgaria.

The necessities of utilization of the European transport corridors that tangent or cross the country have been analyzed. Some variants for tracing of the Pan-European corridors have also been proposed. The geopolitical advantages of each one of them have been pointed out and analyzed through the prism of the political-geographical assessment and analysis. The possible socio-economic effect of the transformation of the territory of Bulgaria into an active integration zone has also been discussed. Some activities for preventing Bulgaria from turning into a European transport enclave have been proposed. The purpose of the research has been achieved with the help of different research methods, including system and complex approach, situation and comparative analyses and others.
\end{abstract}

Keywords: infrastructure, Pan-European transport corridors, geographical position, valorization, integration

\section{INTRODUCTION}

The transport integration of Bulgaria is a process that became very topical after the political changes that took place in Eastern Europe as a whole and in the Balkans in particular. It also determines new standpoints, concerning the transport corridors connecting the country with the states in the region and outside of it.

In the process of globalization, socio-economic relations predetermine the necessity of construction and optimal functioning of an infrastructure network, which will most adequately fulfil the objective social needs. It is a precondition for the accomplishment of the integration process. The necessity for our country to become accessible for its neighbours and Europe requires the construction and functioning of infrastructure corridors, whose routes, from the global perspective, are determined by the European Union Transport Committee. 


\section{THE PRESENT SITUATION}

From the most general point of view the transport configuration is the economic grating of the territory. However, its intensity and activation depends on political and geographical factors. The intension for building of impressive infrastructure projects on the territory of Bulgaria hints about the necessity our country to be included in the European economic architecture and its willingness to suppress its internal sense of infrastructure inferiority. It is stimulated by several significant circumstances.

First - by the process of appropriation of the Balkan space, because of its geographic predetermination and historical past.

The orientation of Bulgaria to the semi-closed economic relations of the Eastern economic block, where the lack of competition didn't stimulate the building of optimal transport network, led to the formation of centripetal transport relations and to the construction of parallel neighbouring peripheral transport zones, which could hardly be overcome in the conditions of opposing manners of economic communication.

Second - the relatively dynamically changing range of the countries in the region and the connected with this process element of insecurity, spontaneity and political situation lead to the lack of strategy for the development of the sector.

On the third place - the lack of flexible political and socio-economic management hinders the objective extrapolation of the Balkan processes. As a result, usually we get to the situation, in which most applicable is the tactics of "catching up".

In the relatively uncontrolled by the EU Balkan economic space, significant role has Turkey, whose present positions are good base for planning of more distant in the future trade invasion of Europe. And if the Turks together with Greece have great opportunities and their former actions show that they intend to use them, examining the transport network of XXI century, the chance for Bulgaria not to turn into a deep hinterland is in the effective diplomacy. At the same time the state should overcome the "borders against transport networks" problem.

The present situation demands energetic and pragmatic actions for building of alternative transport connections. This supposes the concentration of efforts into the following directions:

- Accelerated development of the infrastructure connecting the country with the European countries;

- Introduction and elaboration of the systems for combined transportation with the participation of Bulgarian transport;

- Legislative regulation of the integration processes in European transport;

- Improvement of the transport policy and its closer binding to the development of the European integration.

\section{THE PANEUROPEAN TRANSPORT CORRIDORS}

Evidence about the strategic and geopolitical position of the country is the fact that 5 out of the 10 European corridors tangent or cross the territory of Bulgaria. This obliges us to approach very soberly and in the same time dynamically when determining the routes of the Euro corridors, as well as the consequence of their construction. The right choice will be result of an analytical assessment (from politico-geographical and geopolitical point of view) of the situation connected with the construction of each one of the routes.

According to M. Devedzhiev no one of the Balkan states can reveal its geopolitical potential by itself, since infrastructure connections lose their significance if they only 
reach the borders of the country [1]. This unity is a powerful factor for the Balkan integration, whose importance has not been fully clarified yet and is not used properly. The opening of the national borders is not an end in itself, but a consequence of the political reality in the Balkans. Without mutual interest and common agreement such an opening would not be possible. And it is necessary even only because of the fact that the share of the Balkan region in the general trade of Bulgaria is an offendingly small - just $11 \%$. A value that predetermines its passive participation in the creation of euroregional forms of cooperation in the Balkans.

As far as Corridor 7 still has the role of an infrastructural facade of Bulgaria, its geostrategic significance will be revealed in some time. For the time being, it is almost unused, because of some objective (the lack of sufficiently reliable and qualitative river fleet, of solvent and economically motivated consumers, impossibility to conduct the traffic during the dry summers) and subjective reasons (the river traffic, directed from Western and Central Europe to the East has as final destination one distant from the main consumers and still infrastructurally unprovided zone). Unfavourable for Bulgaria is the fact that there is a parallel land route in the direction Constanta-Bucharest-AradBudapest, most of it built, which now takes some of the eventual transport traffic of Corridor 7 [4].

Infinitely complicated and difficult to comment is the situation of Euro corridor 4. Its development was tightly connected with the situation of the second bridge on the Danube in the Bulgarian-Romanian section of the river. Although the negotiations led to its localization at Vidin-Calafat and they were considered a great success of Bulgarian diplomacy, some facts make us be reserved regarding such major assessments. The first one is connected with the condition the route to be "pulled" in Eastern direction on Romanian territory, forming an almost 200 kilometres long arc along the valley of the Jiu river, through the traditionally restless miners Carpathian region, as a compensation for the Romanian agreement the bridge to be built at Calafat - in the westernmost part of the Bulgarian-Romanian Danubian section, having in mind the fact that only $60 \mathrm{~km}$ upstream the river there are two bridges on the Danube - at the "Iron Gates". This horseshoe-like curve is economically unprofitable for Western Europe, as well as for Bulgaria and the end user - Greece. The fact that from our southern neighbour's side, famous for the eager defending of its own interests, didn't come any reactions, makes us reach the conclusions that Greece doesn't take Euro corridor 4 seriously enough, and that it considers it an alternative variant for land transport traffic to Europe.

Another is the question that the project in its initial form (with a tunnel under the Petrohan Peak in the Balkan Mountains, and its further construction through the narrow Kresna Gorge) is difficult to be realized. Much more profitable for Greece is the corridor Belgrade-Skopje-Thessaloniki (along the Morava and Vardar rivers), which a number of western economic geographers recognize as the main meridian pan-Slav transport corridor on the Balkans. The advanced phase of its development, predestined by the radial centripetal connections, created in former Yugoslavia, and the shorter length of the route, give it the role of a favourite, compared to Corridor 4 on Bulgarian territory. The last one can function justifiable only if the Albanian demographical and political expansion to the North of the Serbian-North Macedonian border "flows" to the East of Kosovo, along the Morava River, embraces the Western outskirts (stopping (!) at the frontier with Bulgaria) and as a Muslim arc liquidates the existence of a straight political border between North Macedonia and Serbia. This would question the functioning and the perspectives of the corridor along the Morava and Vardar Rivers. Which would be extremely unfavourable 
for Greece, because thus political preconditions for the formation of a pro-Muslim parallel axis Turkey - partially Bulgaria - "Great Albania" are created, weld together by the relevant parallel Euro corridor. Its construction corresponds to the formation of the legal framework of cooperation among the countries, interested in the development and the using of a corridor like this (Bulgaria, North Macedonia, Albania, Turkey, Italy), that is to say the Memorandum of understanding, concerning the development of Pan-European transport corridor 8, signed in September 2002 in the Italian town of Bari.

The dynamics of the political situation on the Balkans, accompanied by the interests of the USA and Russia in marking out the Caucasian and the Middle-Asian oil in Europe, make the building of Corridor 8 problematic. Things get more difficult, because of the improving political and economic relations between Greece and Macedonia, the result of which is the opening of the oil pipe-line from Thessaloniki to Skopje. Even more, this turns Corridor 8 into the reserve parallel Southern route on the Balkans, where undoubted favourite is the direction Bari-Igoumenitsa-Ioannina-Thessaloniki-Kavala-Istanbul, famous with the old Roman name "Via Egnatia". As member of the European Union, Greece, taking advantage of its structural funds, invests intensively capitals to get it finalized. Another problem is the fact that the Bulgarian ports of Varna and Burgas need reconstruction in order to be able to take the traffic from the corridor [3].

Counterpoint of the advantages that were listed, are the traditionally delicate political relations between Greece and Turkey, of which Bulgaria should take advantage, promoting more persistently the positive features of Euro corridors 8 and 10. The last one, which stretches diagonally in North-East - South-East direction, is considered to be a branch of Corridor 4 towards Serbia and a subparallel alternative of Corridor 8 .

For Bulgaria the construction of transport Corridor 8 doesn't have only economic significance. When it gets an outlet on the Marmora Sea it will expand its influence in the Bulgarian diaspora southern from the Strandzha Mountain. The conditions for construction of a railway between Sofia and Skopje are extremely favourable, because it will take place on the old route, which have been projected and built whole century. And while from the North Macedonian side should be built $85 \mathrm{~km}$ road and two new stations, 26 tunnels, long 5,4 km altogether, and 43 bridges long 2,5 km, Bulgaria should build only $1,5 \mathrm{~km}$ railway and equip the border tunnel [7].

Also a reconstruction of the railway Radomir-Kyustendil-Gyueshevo should be done to increase the speed up to $130 \mathrm{~km} / \mathrm{h}$ and to make combined transportation along the corridor possible.

In order more tight economic relations to be organized, new border crossings should be established: Berovo-Mikrevo, Pehchevo-Simitli and Delchevo-Tsarvenitsa [6].

The perspective for Bulgaria to turn into one of the biggest transport hubs on the Old Continent seems to be very real with the accomplishment of the project for pan European highway connecting the Adriatic and the Black Sea [2]. The construction of a stable railway connection between the Bulgarian ports and the western border needs serious investments, but the prospects for return in the near future are promising.

From the political-geographical overview we already made, is obvious the objective conjuncture of our infrastructural subjectification. Among other things, the likelihood of realization of whichever of the projects, is connected also with objective political processes, like the speed of incorporation of our country to the European structures, observing of preliminarily regulated international contracts, stabilization of the internal political processes, irreversibility of our foreign-political and foreign-economic orientation, and so on. 
Compared to all of the Euro corridors reviewed here, and in spite of its problems (the crossing of Veliko Tarnovo, where the tunnels are not suitable for international traffic, and the tunnel under the peak of Shipka, which is still only in discussions and on paper), as if Corridor 9 proves to be most stable, from the point of view of the political will to be developed, demonstrated by all the 7 states, through which it will pass. It is especially important for Bulgaria, because it crosses our country in meridian direction almost through its middle, and has the role of a "bearing arm", of a "welding axis" of the socioeconomic intra- and interregional processes. Being a part of the Helsinki-Alexandroupoli route, Bulgaria is dragged into the meridional European integration process, affecting territories of Old Europe, as well as new lands of the European Union, and those "buffer zones" between the continent and Russia, which although not stabilized economically and politically, have great integration potential.

However, all of these problems are also connected with the infrastructure system within the borders of Bulgaria. Although a lot of resources are invested in transport infrastructure, they are scattered in different parts of the country, and it can hardly be said that there is a consecutive policy in the construction of highways, roads and other projects, that is bound to a long term strategy for the development of the economy, regional development and so on. Today the inadequate development of the transport infrastructure of Northern Bulgaria is considered to be one of the main reasons for its economic and social lagging. This part of the country, surrounded by the Danube River to the North and by the Balkan Mountains to the South, has just two bridges on the Danube, along the 470kilometers long river border. The 530-kilometers-long Balkan Mountains are crossed just in three places by the railway system, and there is not a single tunnel which should facilitate the transportation between the Northern and the Southern part of the country. Thus, in the era of European integration and the extremely important significance of the cross-border euroregions, because of its difficult transport accessibility Northern Bulgaria remains isolated in this natural European crossroad. Furthermore, all this leads to negative economic and social trends as decreasing of foreign investments and depopulation [5].

The highway network in Bulgaria also shows the same trends of development. In 2019 our country has $812 \mathrm{~km}$ highways, which makes up 54\% of the planned high class roads. The longest one which is in exploitation is $360 \mathrm{~km}$, connecting Sofia and Burgas. The connections with the borders are missing, so the already built parts are not attractive for transit traffic. Some of the first class roads are not in good condition.

The European Union determined the priority axes for development of the transport infrastructure for the period 2014-2020, and two of them pass through Bulgaria.

Basing on the analysis of the European policy, concerning the paneuropean corridors on the territory of Bulgaria have been determined four main priorities for work:

Priority 1: most important axes for development of the paneuropean transport system the route Vidin-Sofia-Kulata along Corridor 4, connected with a project for modernization of the railway in the same direction, and the Danube River (Corridor 7), connected with a project for improvement of the navigation along the river.

Priority 2: most important axes for connection of the EU with the neighbouring countries and regions:

- Corridor 10 - branch C, between Belgrade-Nish-Sofia-Plovdiv-IstanbulTRACECA;

- Corridor 8 - Durres-Tirana-Skopje-Sofia-Plovdiv-Burgas-Varna;

- sea waterways - the connections of the ports of Varna and Burgas with the ports in Ukraine, Russia, Georgia and Turkey. 
Priority 3: European corridors, which are not covered by the main axes - Corridor 9 Bucharest-Ruse-Dimitrovgrad-Alexandroupoli.

Priority 4: additional connections of the TINA network: railway connection MezdraPleven-Gorna Oryahovitsa; railway connection Ruse-Kaspichan-Sindel; road connection Botevgrad-Pleven-Byala; road connection Svilengrad-Burgas.

The position of the Bulgarian authorities supports the idea that Bulgaria is a bridge between Asia and Europe, and whoever wants to travel in this direction, cannot go round it. But these statements weren't supported by real actions. All of the transport routes crossing Bulgaria - for people and goods, as well as for energy resources, have alternative variants, which shows that the crossroad position of our country is not an exceptional advantage by itself, and in order to be, there is a lot of work to be done. The question which of the routes will be realized depends on the determination and the willingness of the crossed countries for compromises, by the capability of their representatives to negotiate and to get the maximum benefits.

According to the White Paper for transport, issued by the EU, the countries should work on the paneuropean transport network (TEN-T), transfer of cargo from road to railway, sea and internal river transport, development of modern public transport aiming to reduce the usage of private cars, increasing of private capital in the schemes for development of transport [8]. Concentrated on the construction of highways, Bulgaria (and not only it) faces the probability to miss the trends of development of modern European transport, as this happened during the last decades with container loads, combined transport and so on. The integration processes in Europe and the emergence of barriers of different character (economic, political, ecological and others) requires the joint efforts of the different types of transport for their overcoming. In this situation the significance of combined transportation is increasing more and more. Bulgarian railway transport has the necessary equipment to conduct the transportation of containers: specialized railway container terminals in the stations in Sofia, Plovdiv, Stara Zagora, Dimitrovgrad-North, Vratsa, Pleven, Gorna Oryahovitsa, as well as specialized container wagons.

The politico-geographical analysis of the economic map of the Balkans could show some factors hindering the process of transport integration:

1. Mutual duplication of the extent of transport underdevelopment in the border regional units. It also predetermines their comparatively identical intensity of transport services, restricts their possibilities for transport complementation, respectively interchange.

2. Restriction of the interstate transport communications because of the underdeveloped peripheral infrastructure. This problem will be resolved with the realization of international infrastructure problems (the corridors "East-West" and "North-South"), which are going to have not only local effect. The already built bridge Vidin-Calafat, the new border crossings (Gotse Delchev-Drama, Rudozem-Xanthi, Zlatorgrad-Komotini, Podkova-Komotini, Berovo-Mikrevo, Pehchevo-Simitli, Delchevo-Tsarvenitsa), the ferryboat connections (Silistra-Calarasi, Ruse-Giurgiu, Oryahovo-Bechet, Nikopol-Turnu Magurele, Svishtov-Zimnicea, Tutrakan-Oltenita) will lead to intensification of economic activity among the Balkan states, because these facilities will be integrated in the transport system of whole Europe and will cause chain perfection (or new building) of transport sections, that will form significant meridional and parallel corridors on the Balkans.

3. Peripheral presence of the Balkan states (especially of Bulgaria) in the global transport schemes of the "Big countries". Evidence for that is the slow pace of the 
negotiations about the building of pipeline routes and practically the secondary role Bulgaria got in them.

Starting point for their solvation is the formation of a national transport strategy, based on social consensus and implemented with diplomatic sense and tact. Or in other words in the current geopolitical situation on the Balkans it is the time for our country to "trade" and win from its distinctive geographical position and image of politically stable country, governed with democratic means.

\section{CONCLUSION}

In the years of imposing of geopolitical ideas for the development of the world, the American geopolitician Alfred Mahan promotes the Atlantic doctrine, which gives the USA the role of anaconda - the snake that while wrapping slowly up the body of its rival, sucks out its vitality. Applied to the Balkans, all that would look like wrapping around the body of Bulgaria of the infrastructural line highways, whose traffic, overtaking ours, indirectly drinks up the vitality of our economy. Thus our country will transform into a peculiar island of transport shortage, an infrastructural enclave of final autarchic type. And the dark prognosis of a number of geopoliticians will come to existence, stating that if Bulgaria doesn't valorize its geographical position, it will be the sanitary revenue stamp of the advancing pseudo-capitalism - easily accessible from outside and hardly from inside.

If the great German geopolitician Karl Haushofer was alive, devoted to his pragmatic feeling, would hint the governers the right answer - aspiration for crossing axis in the heartland of the Balkans and in the heartland of Bulgaria. Bulgaria, which has always stressed upon its geographical position, but most frequently it suffered from its position at an "airy place" at the geographical map, today it has to make efforts to come back to an old tradition - trade connections in all directions, basing on its convenient position as a Balkan crossroad. If it doesn't do that, it will be forced to remember how just until some years ago the land connections with the Baltic states or with Scandinavia for instance, passed through ... Moscow and St. Petersburg, ... and to have semi-autarchic existence in the "backyard" of the Port of Thessaloniki.

The possibility for awaited prosperity of Bulgaria is not hypothetical. It is connected with the realization of social communication, with the more and more offensive attitude of the status quo to the change, with the adaptation of our transport scheme to the European one, with the desire for economic and social extrovercy.

\section{REFERENCES}

[1] Devedzhiev, M. The Geographical Position of Bulgaria - its Chance in XXI Century. Sofia, Bulgaria, 1996.

[2] Devedzhiev, M. Geography of the Transport of Bulgaria. Sofia, Bulgaria, 1996.

[3] Dermendzhiev, A. Politico-geographical Aspects of Transport Corridor 8. - In: Character, Geopolitical Perspectives and Problems of European Transport Corridor 8. Sofia, Bulgaria, pp. 12-17, 2002.

[4] Dermendzhiev, A. Geographical Analyses. V. Tarnovo, Bulgaria, 2004.

[5] Dermendzhiev, A. Geographical Aspects of the Transport Integration of Bulgaria. - In: The Balkans - Language, History, Culture. V. Tarnovo, Bulgaria, vol. 3, pp. 484-494, 2013.

[6] Mihaylov, M. The Border Crossings and the International Transport Corridors of Bulgaria Geoecological Aspects. - In: Geoecology-94, Bulgaria, pp. 42-50, 1994. 
[7] Mutafchiev, L. The European Transport System and Some Problems of the Development of Railway Transport. - In: Railway Transport, Sofia, Bulgaria, vol. 5, pp. 4-7, 2000.

[8] White Paper Roadmap to a Single European Transport Area - Towards a Competitive and Resource Efficient Transport System. Brussels, Belgium, 2011. 